\title{
The Association between Gene-Environment Interactions and Diseases Involving the Human GST Superfamily with SNP Variants
}

\author{
Antoinesha L. Hollman ${ }^{1, *,+}$, Paul B. Tchounwou ${ }^{1,2}$ and Hung-Chung Huang ${ }^{1,2, *,+}$ \\ 1 NIH/NIMHD RCMI Center for Environmental Heath, College of Science, Engineering, \\ and Technology (CSET), Jackson State University, Jackson, MS 39217, USA; paul.b.tchounwou@jsums.edu \\ 2 Department of Biology, CSET, Jackson State University, Jackson, MS 39217, USA \\ * Correspondence: alhollman5@gmail.com (A.L.H.); hung-chung.huang@jsums.edu (H.-C.H.); \\ Tel.: +1-60-1790-0153 (H.-C.H.); Fax: +1-60-1203-5139 (H.-C.H.) \\ + These authors contributed equally to this work.
}

Academic Editor: William Chi-shing Cho

Received: 31 December 2015; Accepted: 14 March 2016; Published: 29 March 2016

\begin{abstract}
Exposure to environmental hazards has been associated with diseases in humans. The identification of single nucleotide polymorphisms (SNPs) in human populations exposed to different environmental hazards, is vital for detecting the genetic risks of some important human diseases. Several studies in this field have been conducted on glutathione S-transferases (GSTs), a phase II detoxification superfamily, to investigate its role in the occurrence of diseases. Human GSTs consist of cytosolic and microsomal superfamilies that are further divided into subfamilies. Based on scientific search engines and a review of the literature, we have found a large amount of published articles on human GST super- and subfamilies that have greatly assisted in our efforts to examine their role in health and disease. Because of its polymorphic variations in relation to environmental hazards such as air pollutants, cigarette smoke, pesticides, heavy metals, carcinogens, pharmaceutical drugs, and xenobiotics, GST is considered as a significant biomarker. This review examines the studies on gene-environment interactions related to various diseases with respect to single nucleotide polymorphisms (SNPs) found in the GST superfamily. Overall, it can be concluded that interactions between GST genes and environmental factors play an important role in human diseases.
\end{abstract}

Keywords: gene-environment interactions; glutathione S-transferases (GSTs); single nucleotide polymorphisms (SNPs); carcinogens; xenobiotics; heavy-metals; air pollutants

\section{Introduction}

Human health or disease development is highly influenced by interactions between gene expression and environment [1]. Glutathione S-transferase (GST) is a dimeric, multifunctional protein superfamily, present in all kingdoms [2,3]; which has sparked an interest in the area of gene-environment interaction and diseases. Recent findings have demonstrated the importance of different allelic frequencies of polymorphic genes, such as GSTs, and susceptibility to certain diseases [4]. Changes or variations in an individual's DNA, such as single nucleotide polymorphisms (SNPs), are deemed to produce numerous diseases [5,6].

GSTs are vital in Phase II detoxification enzymes pathway in humans, and provide protection against toxins by catalyzing toxin conjugation with GSH or passively binding to various exogenous/endogenous toxic molecules, including environmental toxins, carcinogens, chemotherapeutic agents, or products of oxidative stress [3,7]. They are also involved in preventing cellular mutations and aiding in antioxidant defense mechanism. However, there are some instances 
where conjugation reactions can lead to the formation of compounds that are far more toxic than the initial substrate, thereby potentially causing a disease [8]. Some GSTs, which undergo polymorphisms, pose an interest in exploring the relationship between specific allelic variants and the risk of developing a disease [9-13]. Therefore, our goal is to examine studies on gene-environment interactions related diseases, with respect to SNPs found in the GST subfamilies as shown in Table 1 [14].

Table 1. Major types of GST genes and their SNP distributions (based on [14]).

\begin{tabular}{ccccccccccccc}
\hline $\begin{array}{c}\text { Gene } \\
\text { Family }\end{array}$ & $\begin{array}{c}\text { Genome } \\
\text { Location }\end{array}$ & $\begin{array}{c}\text { Total } \\
\text { SNP }\end{array}$ & nsSNP & $\begin{array}{c}\text { \% } \\
\text { nsSNP }\end{array}$ & sSNP & $\begin{array}{c}\text { \% } \\
\text { sSNP }\end{array}$ & $\mathbf{3}^{\prime} \mathbf{U T R}$ & $\begin{array}{c}\text { \% } \\
\mathbf{3}^{\prime} \mathbf{U T R}\end{array}$ & $\mathbf{5}^{\prime} \mathbf{U T R}$ & $\begin{array}{c}\text { \% } \\
\mathbf{5}^{\prime} \mathbf{U T R}\end{array}$ & iSNP & $\begin{array}{c}\text { \% } \\
\text { iSNP }\end{array}$ \\
\hline GSTM & Chr1 & 1072 & 92 & 8.58 & 53 & 4.94 & 55 & 5.13 & 8 & 0.75 & 864 & 80.60 \\
GSTA & Chr6 & 1702 & 98 & 5.76 & 43 & 2.53 & 34 & 2.00 & 21 & 1.23 & 1506 & 88.48 \\
GSTP & Chr11 & 180 & 17 & 9.44 & 6 & 3.33 & 3 & 1.67 & 6 & 3.33 & 148 & 82.22 \\
GSTT & Chr22 & 239 & 30 & 12.55 & 11 & 4.60 & 3 & 1.26 & 5 & 2.09 & 192 & 80.33 \\
Total & 3193 & 237 & 7.42 & 113 & 3.54 & 95 & 2.98 & 40 & 1.25 & 2710 & 84.87 \\
\hline
\end{tabular}

The mechanisms for the genetic variances can be complex. Conventionally there are two kinds of mutations, germinal and somatic mutations [15,16]. Germinal mutations can be passed down to offspring generations to become inherited mutations or polymorphisms. Inherited polymorphisms, unlike somatic mutations, are congenital and not induced by environmental factors. Somatic mutations develop at some stage of the cell lifespan due to exposure to environmental hazards. The focus of this article is on the SNP polymorphisms caused by somatic mutations induced by environmental risk factors. Nonetheless, the subtle differences (variances) of inherited genetics for different race/ethnic group populations in different locations, may confer different susceptibilities to somatic mutations induced by some factors (Table 2).

\section{Glutathione S-transferases (GSTs)}

The first GST structure, in 1991, leads to an overflow of structural data among GSTs of the three distinct superfamilies: the cytosolic GSTs (largest), the mitochondrial GSTs and microsomal, also known as the membrane-associated proteins in eicosanoid and glutathione metabolism (MAPEG family) [17]. Several mammalian GST classes have been identified and characterized, forming eight distinct classes: alpha, mu, pi, omega, sigma, theta, zeta, and kappa; with the first seven being cytosolic specific [18,19]. Alpha, mu, and pi are noted being the major classes [20] with their SNP distributions shown in Table 1 [14]. An extensive amount of literature has been published on theta, as well [14,21], which SNP distribution can also be seen in Table 1. In some cases, GSTM1 (glutathione S-transferase $\mathrm{mu}$ ), GSTT1 (glutathione S-transferase theta), and GSTP1 (glutathione S-transferase pi) are evaluated in experiments altogether. GSTs are present in virtually all tissues, yet in humans the liver has the highest cytosolic GST activity level. Those major cellular detoxification enzymes are present mostly in the liver and kidney, as well as in the intestine [22].

The four widely studied GSTs (GSTA, GSTM, GSTP, and GSTT) are parts of the cytosolic GST group and are involved in the detoxification of xenobiotics, carcinogens, and therapeutic drugs. Hence, they are deemed insightful biomarkers as some of their polymorphic states can increase an individual or population's susceptibility to a disease (e.g., cancer). Class alpha GST (GSTA), located on chromosome 6 and highly expressed in the liver, plays a role in cell protection in the presence of peroxidation products and reactive oxygen species (ROS). It can serve as an indicator for liver injury, as it can be detected at lower levels in acute hepatic injury [23]. Class mu (GSTM), located on chromosome 1, is known to modify the toxicity and effectiveness of medical drugs. Class pi (GSTP), located on chromosome 11, is involved in the protection of cells from cytotoxic and carcinogenic agents [24]. Lastly, class theta (GSTT), located on chromosome 22, shares a similarity with $55 \%$ amino acid sequence identity and possesses a possible role in human carcinogenesis. Most GSTs' functions 
are associated with detoxification or anti-oxidation processes. Therefore, their structural changes due to SNP variants (especially missense mutations) have a strong correlation with chronic diseases such as cancers.

Glutathione S-transferase alpha (GSTA) family consists of GSTA1, GSTA2, GSTA3, GSTA4, GSTA5, GSTA6P (pseudogene), and GSTA7P (pseudogene) that are located on chromosome 6. This class encodes enzymes with glutathione peroxidase activities that function in the detoxification of lipid peroxidation products. Glutathione S-transferase mu (GSTM) family includes GSTM1, GSTM2 (muscle), GSTM3 (brain), GSTM4, and GSTM5, found on chromosome 1. GSTM1 enzyme encodes a major detoxification phase enzyme that helps detoxify various xenobiotics. Deficiency in GSTM1 activity is related to homozygous deletion of GSTM1 (GSTM1 null), leading to a lack of corresponding enzymatic activity [8,25]. Glutathione S-transferase pi (GSTP1) has an enzymatic activity that provides a "caretaker" function. It has been documented that inactivation of the GSTP1 gene was often observed in human neoplasia (prostate, breast, and liver cancer, as well as leukemia) and researchers highlight GSTP1 epigenetic modifications as biomarkers for early diagnosis for cancers and potential targets of preventive or therapeutic treatments [26,27]. Glutathione S-transferase theta (GSTT) family is comprised of GSTT1, GSTT2 (gene/pseudogene), and GSTT2B (gene/pseudogene) and is positioned on chromosome 22. This gene is polymorphic in human and the null genotype results in the absence of enzyme function, which may influence alterations in the response of xenobiotics. In recent years, many studies have assessed the associations between diabetes mellitus (DM), Type 2 diabetes mellitus (T2DM) and GSTT1 polymorphism; although no significant association was found [28], GST polymorphic genes (GSTM1-null and GSTT1-null) can be used as biological markers to determine the diabetic risk of individuals [4].

DNA mutations are associated with many human diseases and are the reasons for the variations among individuals. Many polymorphisms in the DNA sequence of these GSTs are reported and many studies have demonstrated that the polymorphisms of these GSTs are associated with different types of cancer $[5,6,29,30]$. As studied by Yadav et al. [14] based on NCBI/dbSNP database, the major studied GST genes [14] contained 3193 SNPs with 237 coding nsSNP among them (Table 1) which should be the focus of the investigation due to their potential effects on the structure, function, interactions, and other properties of DNA and expressed proteins. Obviously, intron noncoding SNPs consist of the most percentage (84.87\%) of total SNPs under study; these intronic SNPs will not be the focus of our current review, although some of them may relate to regulatory or splicing mechanism. Significant coding nsSNPs will be identified and highlighted in the next section.

Table 2. Population susceptibility for different diseases related to major types of GST.

\begin{tabular}{|c|c|}
\hline Gene Family & Population Susceptibility \\
\hline GSTM & $\begin{array}{l}\text { Chinese (LAC) [31], Indian (OC) [32], North Indian (CC) [33], } \\
\text { Caucasians (CRC) [34], Iranian (BC) [35] }\end{array}$ \\
\hline GSTA & Brazilian (PCa) [36] \\
\hline GSTP & Asian (BC) [37], Iranian (BC) [35], Saudi Arabian (DLBCL) [38] \\
\hline GSTT & $\begin{array}{l}\text { North Indian (CC) [33], Chinese (LC) [39], Caucasians (CRC) } \\
\text { [34], Chinese (GC) [40], Saudi Arabian (DLBCL) [38] }\end{array}$ \\
\hline
\end{tabular}

Abbreviations: BC-Breast Cancer; CC—Cervical Cancer; CRC—Colorectal Cancer; DLBCL-Diffuse Large B-cell Lymphoma; GC-Gastric Cancer; LAC—Lung adenocarcinoma; LC-Lung Cancer; OC—Oral Cancer; $\mathrm{PCa}-$ Prostate Cancer.

\section{GST Single Nucleotide Polymorphisms (SNPs)}

GST genes are organized in chromosomal clusters, and most of these genes are polymorphic, mainly due to single nucleotide substitutions or variations (i.e., SNPs). Genetic variations can be classified as synonymous or nonsynonymous. Synonymous variation is the alteration in the DNA, which produces a change in the amino acid due to the nucleotide change, but does not affect 
the function. However, missense, nonsense, and frameshift changes are types of nonsynonymous mutations that all generate a significant change in the protein. In recent years, a few researchers suggested that deleterious nonsynonymous single nucleotide polymorphisms (nsSNP) of GSTs are associated with diseases. One study [14] discovered that five (GSTA3/R13W, GSTA3/Y147D, GSTM3/R191L, GSTM4/R18L, and GSTT1/W101R) of 237 nsSNP were identified as potential target mutations that induced structural changes and possibly alter the detoxification process that could lead to carcinogenesis events (Table 3).

It has also been recognized that there are modifications in enzymatic activity of a missense categorized SNP in GSTP1 (rs1695/lle105Val) at residue 105 that leads to miscellaneous diseases [9-13]. Internationally, it has been determined that the GSTP1 Val105 allele occurs more frequently in African-Americans (42\%) and European-Americans (33\%) versus other ethnicities, such as Chinese $(22 \%)$, Taiwanese (18\%), and Japanese (14\%) populations, while in the nsSNP Ala114Val, GSTP1 Val114 allele is not common in African-Americans (5\%) or European-Americans (9\%) [41].

\subsection{Significant GST SNPS}

Based on the literature reviewed, we compiled the most significant GST SNPs (related to disease) in Table 3. The criteria used to obtain information for this paper were based on the major GST-related \& disease-associated SNPs found in PubMed, a service that provides access to literature, and dbSNP, NCBI's database containing genetic variation data. In Table 3, we included the significant or potential SNPs that fit our criteria which are: (1) the SNP was located in GST gene or close to it; (2) the SNP was studied and described in some literature(s) in PubMed; (3) the SNP has a dbSNP ID; (4) the SNP formation was susceptible to some kind of environmental factor including variances in ethnic group and living locations; (5) the SNP was associated with a disease or has the potential to cause a disease. Although some significant SNPs are located in the noncoding areas (e.g., GSTM5/rs3754446, GSTA1/rs3957357, GSTP1/rs4147581, GSTP1/rs947895, GSTT1/rs4630, GSTO2/rs7085725, and GSTZ1/rs1468951 in Table 3), most significant GST SNPs are found in the coding areas which can have a strong effect on the structure and function of the translated protein due to consequent amino acid change on the SNP site. Most of the SNPs in Table 3 have a connection with the environmental factors including carcinogen, toxin, heavy metal, cigarette smoke, air pollutant, UV exposure, and other environmental hazards. GSTA2 (P110S, S112T, and E210A) are in linkage disequilibrium (with one another), as shown in Table 3, which displays potential damage by these three GSTA2 variants collectively [42] although it has only been shown that GSTA2 S112T serine allele homozygosity is a prognostic factor for poorer survival, for increased any time- and 100-day transplant-related mortality [43]. It was determined that some contributing factors related to SNP formation can be associated with ethnic group's different susceptibility, location for industrial waste toxin or heavy metal, and other environmental factors. Our focus is on the somatic variances that are associated with environmental factors which may induce a potential disease, including the possibilities of disease susceptibility depending on a specific ethnic/population group with different living habits in a certain location (Table 2). In addition, most GST SNPs are linked to carcinogenesis. 
Table 3. Significant GST SNPs related to miscellaneous diseases or mechanisms.

\begin{tabular}{|c|c|c|c|c|c|c|}
\hline Variation & dbSNP ID & $\begin{array}{c}\text { SNP } \\
\text { Category }\end{array}$ & $\begin{array}{l}\text { Nucleotide } \\
\text { Change }\end{array}$ & Affecting Factor & $\begin{array}{l}\text { Related Disease or } \\
\text { Mechanism }\end{array}$ & Reference \\
\hline GSTA1/NG5-69C/T & rs3957357 & Noncoding & $\mathrm{C}-\mathrm{T}$ & $\begin{array}{l}\text { Ethnic Group, } \\
\text { Location }\end{array}$ & Asthma, Allergy & {$[44]$} \\
\hline GSTA2/P110S & rs2234951 & Missense & $\mathrm{C}-\mathrm{T}$ & Environment & Strong LD* & [42] \\
\hline GSTA2/S112T & rs2180314 & Missense & $\mathrm{G}-\mathrm{C}$ & Environment & $\begin{array}{l}\text { Transplant-related } \\
\text { mortality, Strong LD * }\end{array}$ & {$[42,43]$} \\
\hline GSTA3/R13W & rs59410661 & Missense & $A-G$ & Universal & Carcinogenesis & [14] \\
\hline GSTA3/Y147D & rs144126679 & Missense & $\mathrm{A}-\mathrm{C}$ & Universal & Carcinogenesis & [14] \\
\hline GSTM1/K173N & rs1065411 & Missense & $\mathrm{G}-\mathrm{C}$ & Cigarette Smoking & Colorectal Cancer & {$[45]$} \\
\hline GSTM1/T154S & rs135955605 & Missense & $C-G$ & $\begin{array}{l}\text { Climate, } \\
\text { Environment }\end{array}$ & Bull Sperm Quality & [46] \\
\hline GSTM5/NG5 & rs3754446 & Noncoding & $\mathrm{T}-\mathrm{G}$ & Ethnic Group & AML & [47] \\
\hline GSTP1/I105V & rs1695 & Missense & $A-G$ & $\begin{array}{l}\text { Arsenic, } \\
\text { Carcinogenic } \\
\text { Compounds }\end{array}$ & $\begin{array}{l}\text { Asthma, BC, } \\
\text { Inflammation, Gastric } \\
\text { Cancer, Autism and } \\
\text { Alzheimer's }\end{array}$ & [9-13] \\
\hline GSTP1/A114V & rs1138272 & Missense & $\mathrm{C}-\mathrm{T}$ & Ethnic Group & MND & {$[41,48]$} \\
\hline GSTP1/S185S & rs4891 & Synonymous & $\mathrm{T}-\mathrm{C}$ & Cigarette Smoking & Lung Cancer & {$[49]$} \\
\hline GSTP1/intron & rs4147581 & Noncoding & $\mathrm{G}-\mathrm{C}$ & $\begin{array}{l}\text { Ethnic Grp., } \\
\text { Location }\end{array}$ & $\mathrm{HCC}$ & {$[50]$} \\
\hline GSTP1/NG3 & rs947895 & Noncoding & $\mathrm{C}-\mathrm{A}$ & $\begin{array}{l}\text { Ethnic Grp., } \\
\text { Location }\end{array}$ & Asthma & [51] \\
\hline GSTO2/N142D & rs156697 & Missense & $A-G$ & $\begin{array}{l}\text { Smoking, UV } \\
\text { exposure }\end{array}$ & $\begin{array}{l}\text { Cataract, Asthma, Lung } \\
\text { function }\end{array}$ & {$[44,56,57]$} \\
\hline GSTO2/3'-UTR & rs7085725 & Noncoding & $\mathrm{T}-\mathrm{C}$ & $\begin{array}{l}\text { Ethnic Grp., } \\
\text { Location }\end{array}$ & $\mathrm{HCC}$ & {$[50]$} \\
\hline GSTZ1/E32K & rs7975 & Missense & G-A & Cigarette Smoking & Carcinogenesis & {$[58,59]$} \\
\hline GSTZ1/intron & rs1468951 & Noncoding & $\mathrm{C}-\mathrm{A}$ & Ethnic Group & Cognition & {$[60]$} \\
\hline
\end{tabular}

Abbreviations: BC, Breast Cancer; LD, Linkage Disequilibrium; AD, Alzheimer's Disease; NG5, Near-Gene-5; AML, Acute myeloid leukemia; NG3, Near-Gene-3; MND, Motor Neuron Disease; HCC, Hepatocellular Carcinoma; Missense, Missense SNP; Synonymous, Synonymous SNP; UTR, UnTranslated Region. (Note 1: Universal factor can be environmental or genetic; Note 2: NG5 (Near-gene-5), near $5^{\prime}$ end of the gene; Note 3: NG3 (Near-gene-3), near $3^{\prime}$ end of the gene.). ${ }^{*}$ Strong LD: GSTA2 (P110S, S112T, and E210A) are in linkage disequilibrium (with one another), which displays potential damage by these three GSTA2 variants collectively [42] although it has only been shown that GSTA2 S112T serine allele homozygosity is a prognostic factor for poorer survival, for increased any time- and 100-day transplant-related mortality [43].

\subsection{Databases for GST SNP Studies}

Based on the literatures published so far, we found that dbSNP, HapMap, and HGDP datasets are often utilized and examined for the GST SNP analyses (Table 4). Also, SNPedia and PharmGKB are useful for SNP annotations (Table 4). There are additional SNP datasets to be explored in more recent projects as seen in the databases of COSMIC, ICGC, and TCGA which focus on the genetic changes in cancers (Table 4). 
Table 4. Databases for SNP studies.

\begin{tabular}{lllc}
\hline Database & Focus & Link & Reference \\
\hline 1000 Genomes & Human genetic variation & http://www.1000genomes.org & {$[61]$} \\
\hline COSMIC cancer database & Somatic mutations in cancer & http://cancer.sanger.ac.uk/cosmic & {$[62]$} \\
\hline dbGAP & Genotype, Phenotype & http://www.ncbi.nlm.nih.gov/gap & {$[63-65]$} \\
\hline dbSNP & SNP & http://www.ncbi.nlm.nih.gov/SNP & {$[14,63,64]$} \\
\hline HapMap & $\begin{array}{l}\text { Haplotype map of human } \\
\text { genome }\end{array}$ & http://hapmap.ncbi.nlm.nih.gov & {$[66-70]$} \\
\hline HGDP & Genetic diversity in humans & http://www.hagsc.org/hgdp & {$[69-71]$} \\
\hline ICGC & Oncogenic mutations & https://icgc.org & {$[72]$} \\
\hline PharmGKB & $\begin{array}{l}\text { Genetic variation on drug } \\
\text { response }\end{array}$ & https://www.pharmgkb.org & {$[52,73]$} \\
\hline SNPedia & Effect of DNA variations & http://www.snpedia.com/index.php/SNPedia & {$[74]$} \\
\hline TCGA & Genetic changes in cancers & http://cancergenome.nih.gov & {$[75]$} \\
\hline
\end{tabular}

\subsection{Programs for GST SNP Analyses}

Based on the reviews, there are many programs for SNP analyses and depending on the stage of the analyses, specific program should be used in each stage. For simplicity, we selected a few typical and popular programs to be included in Table 5 for an overall view of the whole process in SNP data analyses. For example, GATK [76] can be the first program to manage the high-throughput raw data for SNP variant discovery and/or genotyping, PLINK [77] can be used to do genome wide association study (GWAS), VEGAS (VEGAS2) [78,79] prepares a gene-based association test via SNP GWAS results, Arlequin $[69,80]$ can perform population allele comparison and analysis of molecular variance (AMOVA), Haploview $[69,81]$ is capable of producing visualizations and plots for the PLINK GWAS results, R/QTL [82] is able to generate a quantitative trait loci analyses to pinpoint the causative SNP loci for the disease, and finally, Triton, SIFT, and Polyphen2 [14,83-86] can evaluate and predict if the SNP is damaging or not (Table 5). Starting from these programs, some more similar or related programs can be identified.

Table 5. Programs for SNP analyses.

\begin{tabular}{|c|c|c|c|}
\hline Program & Application & Link & Reference \\
\hline GATK & $\begin{array}{l}\text { Variant discovery and } \\
\text { genotyping }\end{array}$ & https://www.broadinstitute.org/gatk & [76] \\
\hline PLINK & $\begin{array}{l}\text { Genome association } \\
\text { analysis toolset }\end{array}$ & http://pngu.mgh.harvard.edu/ purcell/plink & [77] \\
\hline VEGAS and VEGAS2 & $\begin{array}{l}\text { Gene-based test for } \\
\text { association via SNP } \\
\text { association results }\end{array}$ & $\begin{array}{l}\text { http:/ /gump.qimr.edu.au/VEGAS; } \\
\text { https://vegas2.qimrberghofer.edu.au }\end{array}$ & {$[78,79]$} \\
\hline Arlequin & $\begin{array}{l}\text { Population allele } \\
\text { comparison and AMOVA }\end{array}$ & http://cmpg.unibe.ch/software/arlequin35 & {$[69,80]$} \\
\hline Haploview & Haplotype analysis & $\begin{array}{l}\text { https://www.broadinstitute.org/scientific-community/ } \\
\text { science/programs/medical-and-population-genetics/ } \\
\text { haploview/haploview }\end{array}$ & {$[69,81]$} \\
\hline R/QTL & $\begin{array}{l}\text { Mapping quantitative } \\
\text { trait loci }\end{array}$ & http://www.rqtl.org & [82] \\
\hline Triton & $\begin{array}{l}\text { Protein mutant construction } \\
\text { and activity prediction }\end{array}$ & http://www.ncbr.muni.cz/triton & {$[14,83,84]$} \\
\hline SIFT & $\begin{array}{l}\text { Predict amino acid } \\
\text { substitution effects }\end{array}$ & http:/ / sift.bii.a-star.edu.sg/ & {$[14,85]$} \\
\hline Polyphen2 & $\begin{array}{l}\text { Predict damaging missense } \\
\text { mutation }\end{array}$ & http://genetics.bwh.harvard.edu/pph2 & {$[14,86]$} \\
\hline
\end{tabular}




\section{Environmental Hazards and Diseases Associated with GST Gene-Environment Interaction}

Living organisms encounter exposure to various toxins and/or toxicants, i.e., industrial chemicals, pesticides, herbicides, air pollutants, pharmaceuticals and several natural occurring substances, that can have a detrimental effect on a human's health. These environmental exposures can induce changes in gene regulation associated with human diseases [7]. Exposure to the same environment does not warrant the same effect on different individuals within or outside of a particular ethnicity, due to the differences in a person's DNA. For example, genome-wide association studies (GWAS) have identified a number of genetic variants connected with the risk of bladder cancer in populations of European descent [87].

A correlation among gene polymorphisms and environmental toxins, such as heavy metals (arsenic, lead, and platinum), air pollutants, and other factors as seen in Table 6, have been the focus for some studies to display the potential risks [88]. Some findings provide information on exposures to environmental lead and an analysis of blood lead levels in men that exhibited genetic polymorphisms in GSTs (deletions of GSTM1/GSTT1 and GSTP1 rs1695), resulting in adverse alterations in inflammatory response [9]. Also, mothers exposed to environmental tobacco smoke show an increased probability of a negative impact on birth weight (i.e., low birth weight) [25]. There is an association between cancer incidence and various disorders of GSH-related enzyme functions especially the alterations of glutathione S-transferases (GSTs) [89]. It has been suggested that GSTM1/T1 polymorphisms are related with many diseases, such as rheumatoid arthritis, age-related macular degeneration, oral leukoplakia, prostate cancer, lung cancer, and cervical neoplasia $[14,45,52,53,90]$. GSTM1 null genotype and GSTP1 Ile105Val polymorphism are associated with the increased risk of Alzheimer's disease [12]. The pi class GST (P1) is often overexpressed in human tumors, including carcinomas of the colon, breast, lung, kidney, ovary, pancreas, esophagus, stomach, prostate, liver, and blood [19,27]. In relation to prostate cancer, there are no consistent associations between GSTM1, GSTT1 or GSTP1 genotypes [91] and related studies produced as recent as 2012 give the same information. Although one study states that its findings revealed no apparent interaction between GST gene variants and hypertension due to exposure to air pollution [21], there are instances where polymorphisms of GSTs are involved (positively or negatively). GSTO1 (glutathione S-transferase omega) related SNP in arsenic (As) metabolism exhibited nominally significant interactions with well-water "As" for connections with cardiovascular disease (CVD), coronary heart disease (CHD), or stroke [92]; in addition, GSTT1 polymorphisms serve as a potential genetic factor for arsenic-induced skin cancer [93]. It is suggested that GSTP1 aids in the detoxification of arsenic [13]. The GSTT1 also encodes enzymes involved in the metabolism and detoxification of polycyclic aromatic hydrocarbons (PAHs), and the protection against genotoxic damage due to the ethylene oxide present in tobacco smoke [25].

In Table 6, it is illustrated that the diseases related to GST SNP variants can be classified into five categories and most of the affecting factors have an association with the environmental toxins or toxicants. The criteria for the creation of this table are to focus on classification of the diseases highly related to SNPs found in GSTs. These five categories of disease are: (1) Cancers; (2) Inflammatory or Immunological Disorders; (3) Neurological Disorders; (4) Aging-related or Metabolic Disorders; and (5) Reproductive Disorders. Environmental toxins are the most important affecting factors for all five categories of diseases and are the causing factors for all cancers, Inflammatory or Immunological Disorders, and Reproductive Disorders. 
Table 6. Miscellaneous diseases or mechanisms related to GST variants.

\begin{tabular}{|c|c|c|c|}
\hline Disease or Mechanism & Affecting Factor & Related GST & Reference \\
\hline \multicolumn{4}{|c|}{ Cancers } \\
\hline Blood Cancer & Misc. Carcinogen and Toxin & GSTM5, GSTP1 & {$[27,47]$} \\
\hline Breast cancer & Misc. Carcinogen and Toxin & GSTP1 & [27] \\
\hline Colorectal cancer & Misc. Carcinogen and Toxin & GSTM1 & [45] \\
\hline Gastric cancer & Misc. Carcinogen and Toxin & GSTP1 & [11] \\
\hline Liver cancer & Misc. Carcinogen and Toxin & GSTP1, GSTO2 & {$[27,50]$} \\
\hline Lung problem or cancer & $\begin{array}{l}\text { Air pollutant, Smoke, Platinum, } \\
\text { Carcinogen }\end{array}$ & GSTM4, GSTP1, GSTO2, GSTZ1 & {$[49,57,59,94]$} \\
\hline Prostate cancer & Misc. Carcinogen and Toxin & GSTP1 & [27] \\
\hline Skin cancer & Arsenic & GST M1, P1, T1, and O1 & {$[92,93]$} \\
\hline \multicolumn{4}{|c|}{ Inflammatory or Immunological Disorders } \\
\hline Asthma & Air pollutant, Smoking, and Toxin & GSTA1, GSTP1, GSTO2 & {$[9-11,44,51]$} \\
\hline Allergy & Air pollutant, Carcinogen, Toxin & GSTA1 & [44] \\
\hline Inflammation & Lead $(\mathrm{Pb})$-induced & GSTM1, GSTP1, GSTT1 & [9] \\
\hline \multicolumn{4}{|c|}{ Neurological Disorders } \\
\hline Alzheimer's disease & Genetics & GSTM1, GSTM3, GSTP1, GSTO1 & {$[12,55,95]$} \\
\hline Autism spectrum disorder & Arsenic & GSTP1 & [13] \\
\hline Brain cognition & Environment & GSTZ1 & [60] \\
\hline Motor neuron disease & Genetics & GSTP1 & [48] \\
\hline Peripheral neuropathy & Immunomodulatory drug & GSTT1 & [54] \\
\hline \multicolumn{4}{|c|}{ Aging-related or Metabolic Disorders } \\
\hline Age-related cataract & Smoking, UV exposure & $\begin{array}{l}\text { GSTM1, GSTT1, GSTO1, and } \\
\text { GSTO2 }\end{array}$ & {$[56,90]$} \\
\hline Cardiovascular disease & Arsenic & GSTM1, GSTT1, GSTO1 & [92] \\
\hline Hypertension & Air pollutant & GSTP1 & [21] \\
\hline Type 2 diabetes & Weight, diet, race, and genetics & GSTM1,GSTT1 & [4] \\
\hline \multicolumn{4}{|c|}{ Reproductive Disorders } \\
\hline $\begin{array}{l}\text { Fetal growth restriction or } \\
\text { adverse pregnancy outcome }\end{array}$ & Environment, smoking, pesticide & GSTM1, GSTT1 & {$[25,88,96]$} \\
\hline Spermatogenesis & Species, environment & GSTM1 & [46] \\
\hline
\end{tabular}

\section{Conclusions}

The findings reviewed in this article display the role of environmental factors and how they influence the genome and its regulation, providing the clue that xenobiotics found in the environment as a result of anthropogenic activities can promote disease by altering gene allele. The study of gene-environment interactions is relevant in improving the human health, as researchers seek to determine risk factors that are potentially due to environmental exposures that produce differences in gene sequences [97]. This would aid in understanding and determining the initiation of the disease and would enhance the chance of protection against those diseases. Though GSTs' detoxifying activity aids in the protection of cells from certain diseases, they are also vulnerable to environmental toxin or hazard for the gene allele change leading to some life-threatening diseases. Hence, we postulate that interactions between GST genes and environmental factors play an important role in adverse health effects among humans. In addition, from recent international projects, there are more cancer SNP datasets available that haven't been fully explored yet, and their detailed examination and analyses in the future can identify more GST SNPs related to various cancers. This can be one step further to approach the practice of gene therapy (editing) via CRISPR/Cas9 [98-100] or disease treatment via personalized precision medicine [101] in the future. 
Acknowledgments: We thank RCMI-Center for Environmental Health at JSU for the funding on this study and publication (NIMHD grant G12MD007581; PI: Paul B. Tchounwou). We also thank Shanell Glass-Bailey for manuscript proof-reading as an English professional with some great suggestions.

Author Contributions: Hung-Chung Huang conceptualized and designed the study, supervised the literature search and review, identified relevant studies, compiled the tables, edited and wrote sections of the manuscript, and approved the final manuscript as submitted. Antoinesha L. Hollman performed the literature search and review, identified relevant studies, and wrote sections of the manuscript. Paul B. Tchounwou contributed to the intellectual content of the manuscript, edited the manuscript, and approved the final manuscript.

Conflicts of Interest: The authors declare no conflict of interest.

\section{References}

1. Edwards, T.M.; Myers, J.P. Environmental exposures and gene regulation in disease etiology. Environ. Health Perspect. 2007, 115, 1264-1270. [CrossRef] [PubMed]

2. Deponte, M. Glutathione catalysis and the reaction mechanisms of glutathione-dependent enzymes. Biochim. Biophys. Acta 2013, 1830, 3217-3266. [CrossRef] [PubMed]

3. Xie, Y.; Zhou, X.; Chen, L.; Zhang, Z.; Wang, C.; Gu, X.; Wang, T.; Peng, X.; Yang, G. Cloning and characterization of a novel sigma-like glutathione $S$-transferase from the giant panda parasitic nematode, Baylisascaris schroederi. Parasit. Vectors 2015, 8, 44. [CrossRef] [PubMed]

4. Shittu, M.O. Polymorphic human glutathione S-transferase genes may predict susceptibility to type 2 diabetes mellitus: A minireview. Int. J. Biomed. Res. 2015, 6, 139-143.

5. Hayes, J.D.; Strange, R.C. Glutathione S-transferase polymorphisms and their biological consequences. Pharmacology 2000, 61, 154-166. [CrossRef] [PubMed]

6. Kucukkal, T.G.; Yang, Y.; Chapman, S.C.; Cao, W.; Alexov, E. Computational and experimental approaches to reveal the effects of single nucleotide polymorphisms with respect to disease diagnostics. Int. J. Mol. Sci. 2014, 15, 9670-9717. [CrossRef] [PubMed]

7. Sturchio, E.; Ficociello, B.; Minoia, C.; Biamonti, G.; Signorini, S.; Moccaldi, A.; Imbriani, M. Gene expression and environmental exposure to xenobiotics: Overview and applications. G. Ital. Med. Lav. Ergon. 2008, 30, 101-114. [PubMed]

8. Bhattacharjee, P.; Paul, S.; Banerjee, M.; Patra, D.; Banerjee, P.; Ghoshal, N.; Bandyopadhyay, A.; Giri, A.K. Functional compensation of glutathione S-transferase M1 (GSTM1) null by another GST superfamily member, GSTM2. Sci. Rep. 2013, 3, 2704. [CrossRef] [PubMed]

9. Sirivarasai, J.; Wananukul, W.; Kaojarern, S.; Chanprasertyothin, S.; Thongmung, N.; Ratanachaiwong, W.; Sura, T.; Sritara, P. Association between inflammatory marker, environmental lead exposure, and glutathione S-transferase gene. Biomed Res. Int. 2013, 2013, 474963. [CrossRef] [PubMed]

10. Palmer, C.N.A.; Doney, A.S.F.; Lee, S.P.; Murrie, I.; Ismail, T.; Macgregor, D.F.; Mukhopadhyay, S. Glutathione S-transferase M1 and P1 genotype, passive smoking, and peak expiratory flow in asthma. Pediatrics 2006, 118, 710-716. [CrossRef] [PubMed]

11. De Araújo, R.M.S.; de Melo, C.F.V.; Neto, F.M.; da Silva, J.N.; Soares, L.F.; de Arruda Cardoso Smith, M.; Sousa, E.C.; Burbano, R.M.R.; de Medeiros, A.C.; Lima, E.M. Association study of SNPs of genes IFNGR1 (rs137854905), GSTT1 (rs71748309), and GSTP1 (rs1695) in gastric cancer development in samples of patient in the northern and northeastern Brazil. Tumour Biol. 2014, 35, 4983-4986. [CrossRef] [PubMed]

12. Wang, M.; Li, Y.; Lin, L.; Song, G.; Deng, T. GSTM1 null genotype and GSTP1 ILE105Val polymorphism are associated with alzheimer's disease: A meta-analysis. Mol. Neurobiol. 2015, 53, 1355-1364. [CrossRef] [PubMed]

13. Rahbar, M.H.; Samms-Vaughan, M.; Ma, J.; Bressler, J.; Loveland, K.A.; Ardjomand-Hessabi, M.; Dickerson, A.S.; Grove, M.L.; Shakespeare-Pellington, S.; Beecher, C.; et al. Role of metabolic genes in blood arsenic concentrations of Jamaican children with and without autism spectrum disorder. Int. J. Environ. Res. Public Health 2014, 11, 7874-7895. [CrossRef] [PubMed]

14. Yadav, P.; Chatterjee, A.; Bhattacharjee, A. Identification of deleterious nsSNPs in $\alpha, \mu, \pi$ and $\theta$ class of GST family and their influence on protein structure. Genomics Data 2014, 2, 66-72. [CrossRef] [PubMed]

15. Peltomäki, P. Mutations and epimutations in the origin of cancer. Exp. Cell Res. 2012, 318, 299-310. [CrossRef] [PubMed] 
16. Tavernarakis, N. Protein synthesis and aging: eIF4E and the soma vs. germline distinction. Cell Cycle 2007, 6, 1168-1171. [CrossRef] [PubMed]

17. Oakley, A. Glutathione transferases: A structural perspective. Drug Metab. Rev. 2011, 43, 138-151. [CrossRef] [PubMed]

18. Konishi, T.; Kato, K.; Araki, T.; Shiraki, K.; Takagi, M.; Tamaru, Y. A new class of glutathione S-transferase from the hepatopancreas of the red sea bream Pagrus major. Biochem. J. 2005, 388, 299-307. [CrossRef] [PubMed]

19. Ruzza, P.; Calderan, A. Glutathione transferase (GST)-activated prodrugs. Pharmaceutics 2013, 5, $220-231$. [CrossRef] [PubMed]

20. Lushchak, V.I. Glutathione homeostasis and functions: Potential targets for medical interventions. J. Amino Acids 2012, 2012, 736837. [CrossRef] [PubMed]

21. Levinsson, A.; Olin, A.-C.; Modig, L.; Dahgam, S.; Björck, L.; Rosengren, A.; Nyberg, F. Interaction effects of long-term air pollution exposure and variants in the GSTP1, GSTT1 and GSTCD genes on risk of acute myocardial infarction and hypertension: A case-control study. PLoS ONE 2014, 9, e99043.

22. Ziglari, T.; Allameh, A. Chapter 13: The significance of glutathione conjugation in aflatoxin metabolism. In Aflatoxins-Recent Advances and Future Prospects; Razzaghi-Abyaneh, M., Ed.; InTech: Rijeka, Croatia, 2013; pp. 267-286.

23. Liu, F.-P.; Ma, X.; Li, M.-M.; Li, Z.; Han, Q.; Li, R.; Li, C.-W.; Chang, Y.-C.; Zhao, C.-W.; Lin, Y.-X. Hepatoprotective effects of Solanum nigrum against ethanol-induced injury in primary hepatocytes and mice with analysis of glutathione S-transferase A1. J. Chin. Med. Assoc. 2016, 79, 65-71. [CrossRef] [PubMed]

24. Vasieva, O. The many faces of glutathione transferase pi. Curr. Mol. Med. 2011, 11, 129-139. [CrossRef] [PubMed]

25. Grazuleviciene, R.; Danileviciute, A.; Nadisauskiene, R.; Vencloviene, J. Maternal smoking, GSTM1 and GSTT1 polymorphism and susceptibility to adverse pregnancy outcomes. Int. J. Environ. Res. Public Health 2009, 6, 1282-1297. [CrossRef] [PubMed]

26. Pompella, A.; Corti, A. Editorial: The changing faces of glutathione, a cellular protagonist. Front. Pharmacol. 2015, 6, 98. [CrossRef] [PubMed]

27. Schnekenburger, M.; Karius, T.; Diederich, M. Regulation of epigenetic traits of the glutathione S-transferase P1 gene: From detoxification toward cancer prevention and diagnosis. Front. Pharmacol. 2014, 5, 1-7. [CrossRef] [PubMed]

28. Afrand, M.; Khalilzadeh, S.; Bashardoost, N.; Sheikhha, M.H. Evaluation of glutathione S-transferase T1 deletion polymorphism on type 2 diabetes mellitus risk in Zoroastrian females in Yazd, Iran. Indian J. Endocrinol. Metab. 2015, 19, 124-128. [CrossRef] [PubMed]

29. Hung, R.J.; van der Hel, O.; Tavtigian, S.V.; Brennan, P.; Boffetta, P.; Hashibe, M. Perspectives on the molecular epidemiology of aerodigestive tract cancers. Mutat. Res. 2005, 592, 102-118. [CrossRef] [PubMed]

30. McIlwain, C.C.; Townsend, D.M.; Tew, K.D. Glutathione S-transferase polymorphisms: Cancer incidence and therapy. Oncogene 2006, 25, 1639-1648. [CrossRef] [PubMed]

31. Wang, J.; Deng, Y.; Cheng, J.; Ding, J.; Tokudome, S. GST genetic polymorphisms and lung adenocarcinoma susceptibility in a Chinese population. Cancer Lett. 2003, 201, 185-193. [CrossRef]

32. Buch, S.C.; Notani, P.N.; Bhisey, R.A. Polymorphism at GSTM1, GSTM3 and GSTT1 gene loci and susceptibility to oral cancer in an Indian population. Carcinogenesis 2002, 23, 803-807. [CrossRef] [PubMed]

33. Singh, H.; Sachan, R.; Devi, S.; Pandey, S.N.; Mittal, B. Association of GSTM1, GSTT1, and GSTM3 gene polymorphisms and susceptibility to cervical cancer in a North Indian population. Am. J. Obstet. Gynecol. 2008, 198, e1-e6. [CrossRef] [PubMed]

34. Economopoulos, K.P.; Sergentanis, T.N. GSTM1, GSTT1, GSTP1, GSTA1 and colorectal cancer risk: A comprehensive meta-analysis. Eur. J. Cancer 2010, 46, 1617-1631. [CrossRef] [PubMed]

35. Hashemi, M.; Eskandari-Nasab, E.; Fazaeli, A.; Taheri, M.; Rezaei, H.; Mashhadi, M.; Arbabi, F.; Kaykhaei, M.-A.; Jahantigh, M.; Bahari, G. Association between polymorphisms of glutathione S-transferase genes (GSTM1, GSTP1 and GSTT1) and breast cancer risk in a sample Iranian population. Biomark. Med. 2012, 6, 797-803. [CrossRef] [PubMed]

36. Så, R.A.; de Moreira, A.D.S.; Cabello, P.H.; Ornellas, A.A.; Costa, E.B.; Matos, C.D.S.; Alves, G.; Hatagima, A. Human glutathione $\mathrm{S}$-transferase polymorphisms associated with prostate cancer in the Brazilian population. Int. Braz. J. Urol. 2014, 40, 463-473. [CrossRef] [PubMed] 
37. Lu, S.; Wang, Z.; Cui, D.; Liu, H.; Hao, X. Glutathione S-transferase P1 Ile105Val polymorphism and breast cancer risk: A meta-analysis involving 34,658 subjects. Breast Cancer Res. Treat. 2011, 125, 253-259. [CrossRef] [PubMed]

38. Al-Dayel, F.; Al-Rasheed, M.; Ibrahim, M.; Bu, R.; Bavi, P.; Abubaker, J.; Al-Jomah, N.; Mohamed, G.H.; Moorji, A.; Uddin, S.; et al. Polymorphisms of drug-metabolizing enzymes CYP1A1, GSTT and GSTP contribute to the development of diffuse large B-cell lymphoma risk in the Saudi Arabian population. Leuk. Lymphoma 2008, 49, 122-129. [CrossRef] [PubMed]

39. Wang, Y.; Yang, H.; Li, L.; Wang, H. Glutathione S-transferase T1 gene deletion polymorphism and lung cancer risk in Chinese population: A meta-analysis. Cancer Epidemiol. 2010, 34, 593-597. [CrossRef] [PubMed]

40. Setiawan, V.W.; Zhang, Z.F.; Yu, G.P.; Li, Y.L.; Lu, M.L.; Tsai, C.J.; Cordova, D.; Wang, M.R.; Guo, C.H.; Yu, S.Z.; et al. GSTT1 and GSTM1 null genotypes and the risk of gastric cancer: A case-control study in a Chinese population. Cancer Epidemiol. Biomarkers Prev. 2000, 9, 73-80. [PubMed]

41. Skrzypczak-Zielinska, M.; Zakerska-Banaszak, O.; Tamowicz, B.; Sobieraj, I.; Drweska-Matelska, N.; Szalata, M.; Slomski, R.; Mikstacki, A. Polymorphisms and allele frequencies of glutathione S-transferases A1 and P1 genes in the Polish population. Genet. Mol. Res. 2015, 14, 2850-2859. [CrossRef] [PubMed]

42. Silva, S.N.; Azevedo, A.P.; Teixeira, V.; Pina, J.E.; Rueff, J.; Gaspar, J.F. The role of GSTA2 polymorphisms and haplotypes in breast cancer susceptibility: A case-control study in the Portuguese population. Oncol. Rep. 2009, 22, 593-598. [PubMed]

43. Bonifazi, F.; Storci, G.; Bandini, G.; Marasco, E.; Dan, E.; Zani, E.; Albani, F.; Bertoni, S.; Bontadini, A.; De Carolis, S.; et al. Glutathione transferase-A2 S112T polymorphism predicts survival, transplant-related mortality, busulfan and bilirubin blood levels after allogeneic stem cell transplantation. Haematologica 2014, 99, 172-179. [CrossRef] [PubMed]

44. Piacentini, S.; Polimanti, R.; Iorio, A.; Cortesi, M.; Papa, F.; Rongioletti, M.; Liumbruno, G.M.; Manfellotto, D.; Fuciarelli, M. GSTA1*-69C/T and GSTO2*N142D as asthma- and allergy-related risk factors in Italian adult patients. Clin. Exp. Pharmacol. Physiol. 2014, 41, 180-184. [CrossRef] [PubMed]

45. Cleary, S.P.; Cotterchio, M.; Shi, E.; Gallinger, S.; Harper, P. Cigarette smoking, genetic variants in carcinogen-metabolizing enzymes, and colorectal cancer risk. Am. J. Epidemiol. 2010, 172, 1000-1014. [CrossRef] [PubMed]

46. Hering, D.M.; Lecewicz, M.; Kordan, W.; Majewska, A.; Kaminski, S. Missense mutation in glutathione-S-transferase M1 gene is associated with sperm motility and ATP content in frozen-thawed semen of Holstein-Friesian bulls. Anim. Reprod. Sci. 2015, 159, 94-97. [CrossRef] [PubMed]

47. Yee, S.W.; Mefford, J.A.; Singh, N.; Percival, M.-E.; Stecula, A.; Yang, K.; Witte, J.S.; Takahashi, A.; Kubo, M.; Matsuda, K.; et al. Impact of polymorphisms in drug pathway genes on disease-free survival in adults with acute myeloid leukemia. J. Hum. Genet. 2013, 58, 353-361. [CrossRef] [PubMed]

48. Gajewska, B.; Kaźmierczak, B.; Kuźma-Kozakiewicz, M.; Jamrozik, Z.; Barańczyk-Kuźma, A. GSTP1 polymorphisms and their association with glutathione transferase and peroxidase activities in patients with motor neuron disease. CNS Neurol. Disord. Drug Targets 2015, 14, 1328-1333. [CrossRef] [PubMed]

49. Gu, J.; Hua, F.; Mei, C.; Zheng, D.; Wang, G.; Zhou, Q. HapMap-based study on the association between MPO and GSTP1 gene polymorphisms and lung cancer susceptibility in Chinese Han population. Acta Pharmacol. Sin. 2014, 35, 636-644. [CrossRef] [PubMed]

50. Qu, K.; Liu, S.-S.; Wang, Z.-X.; Huang, Z.-C.; Liu, S.-N.; Chang, H.-L.; Xu, X.-S.; Lin, T.; Dong, Y.-F.; Liu, C. Polymorphisms of glutathione S-transferase genes and survival of resected hepatocellular carcinoma patients. World J. Gastroenterol. 2015, 21, 4310-4322. [CrossRef] [PubMed]

51. Joubert, B.R.; Reif, D.M.; Edwards, S.W.; Leiner, K.A.; Hudgens, E.E.; Egeghy, P.; Gallagher, J.E.; Hubal, E.C. Evaluation of genetic susceptibility to childhood allergy and asthma in an African American urban population. BMC Med. Genet. 2011, 12, 25. [CrossRef] [PubMed]

52. Thorn, C.F.; Ji, Y.; Weinshilboum, R.M.; Altman, R.B.; Klein, T.E. PharmGKB summary: Very important pharmacogene information for GSTT1. Pharmacogenet. Genomics 2012, 22, 646-651. [CrossRef] [PubMed]

53. Moyer, A.M.; Salavaggione, O.E.; Hebbring, S.J.; Moon, I.; Hildebrandt, M.A.T.; Eckloff, B.W.; Schaid, D.J.; Wieben, E.D.; Weinshilboum, R.M. Glutathione S-transferase T1 and M1: Gene sequence variation and functional genomics. Clin. Cancer Res. 2007, 13, 7207-7216. [CrossRef] [PubMed] 
54. Cibeira, M.T.; de Larrea, C.F.; Navarro, A.; Díaz, T.; Fuster, D.; Tovar, N.; Rosiñol, L.; Monzó, M.; Bladé, J. Impact on response and survival of DNA repair single nucleotide polymorphisms in relapsed or refractory multiple myeloma patients treated with thalidomide. Leuk. Res. 2011, 35, 1178-1183. [CrossRef] [PubMed]

55. Capurso, C.; Panza, F.; Seripa, D.; Frisardi, V.; Imbimbo, B.P.; Verdile, G.; Vendemiale, G.; Pilotto, A.; Solfrizzi, V. Polymorphisms in glutathione S-transferase omega-1 gene and increased risk of sporadic Alzheimer disease. Rejuvenation Res. 2010, 13, 645-652. [CrossRef] [PubMed]

56. Stamenkovic, M.; Radic, T.; Stefanovic, I.; Coric, V.; Sencanic, I.; Pljesa-Ercegovac, M.; Matic, M.; Jaksic, V.; Simic, T.; Savic-Radojevic, A. Glutathione S-transferase omega-2 polymorphism Asn142Asp modifies the risk of age-related cataract in smokers and subjects exposed to ultraviolet irradiation. Clin. Exp. Ophthalmol. 2014, 42, 277-283. [CrossRef] [PubMed]

57. De Jong, K.; Boezen, H.M.; Hacken, N.H.T.; Postma, D.S.; Vonk, J.M. GST-omega genes interact with environmental tobacco smoke on adult level of lung function. Respir. Res. 2013, 14, 83. [CrossRef] [PubMed]

58. Blackburn, A.C.; Tzeng, H.F.; Anders, M.W.; Board, P.G. Discovery of a functional polymorphism in human glutathione transferase zeta by expressed sequence tag database analysis. Pharmacogenetics 2000, 10, 49-57. [PubMed]

59. Qiu, P.; Wang, L.; Kostich, M.; Ding, W.; Simon, J.S.; Greene, J.R. Genome wide in silico SNP-tumor association analysis. BMC Cancer 2004, 4, 4. [CrossRef] [PubMed]

60. Schoormans, D.; Li, J.; Darabi, H.; Brandberg, Y.; Sprangers, M.A.G.; Eriksson, M.; Zwinderman, K.H.; Hall, P. The genetic basis of quality of life in healthy Swedish women: A candidate gene approach. PLoS ONE 2015, 10, e0118292. [CrossRef] [PubMed]

61. Abecasis, G.R.; Altshuler, D.; Auton, A.; Brooks, L.D.; Durbin, R.M.; Gibbs, R.A.; Hurles, M.E.; McVean, G.A. A map of human genome variation from population-scale sequencing. Nature 2010, 467, 1061-1073. [PubMed]

62. Forbes, S.A.; Beare, D.; Gunasekaran, P.; Leung, K.; Bindal, N.; Boutselakis, H.; Ding, M.; Bamford, S.; Cole, C.; Ward, S.; et al. COSMIC: Exploring the world's knowledge of somatic mutations in human cancer. Nucleic Acids Res. 2014, 43, D805-D811. [CrossRef] [PubMed]

63. Wheeler, D.L.; Chappey, C.; Lash, A.E.; Leipe, D.D.; Madden, T.L.; Schuler, G.D.; Tatusova, T.A.; Rapp, B. Database resources of the National Center for Biotechnology Information. Nucleic Acids Res. 2000, 28, 10-14. [CrossRef] [PubMed]

64. NCBI Resource Coordinators. Database resources of the National Center for Biotechnology Information. Nucleic Acids Res. 2015, 43, D6-D17.

65. Gelernter, J.; Kranzler, H.R.; Sherva, R.; Almasy, L.; Herman, A.I.; Koesterer, R.; Zhao, H.; Farrer, L.A. Genome-wide association study of nicotine dependence in American populations: Identification of novel risk loci in both African-Americans and European-Americans. Biol. Psychiatry 2015, 77, 493-503. [CrossRef] [PubMed]

66. Altshuler, D.M.; Gibbs, R.A.; Peltonen, L.; Dermitzakis, E.; Schaffner, S.F.; Yu, F.; Bonnen, P.E.; de Bakker, P.I.W.; Deloukas, P.; Gabriel, S.B.; et al. Integrating common and rare genetic variation in diverse human populations. Nature 2010, 467, 52-58. [CrossRef] [PubMed]

67. Polimanti, R.; Piacentini, S.; Fuciarelli, M. HapMap-based study of human soluble glutathione S-transferase enzymes: The role of natural selection in shaping the single nucleotide polymorphism diversity of xenobiotic-metabolizing genes. Pharmacogenet. Genomics 2011, 21, 665-672. [CrossRef] [PubMed]

68. Polimanti, R.; Piacentini, S.; De Angelis, F.; De Stefano, G.F.; Fuciarelli, M. Human GST loci as markers of evolutionary forces: GSTO1*E155del and GSTO1*E208K polymorphisms may be under natural selection induced by environmental arsenic. Dis. Markers 2011, 31, 231-239. [CrossRef] [PubMed]

69. Polimanti, R.; Carboni, C.; Baesso, I.; Piacentini, S.; Iorio, A.; De Stefano, G.F.; Fuciarelli, M. Genetic variability of glutathione S-transferase enzymes in human populations: Functional inter-ethnic differences in detoxification systems. Gene 2013, 512, 102-107. [CrossRef] [PubMed]

70. Karaca, S.; Karaca, M.; Cesuroglu, T.; Erge, S.; Polimanti, R. GSTM1, GSTP1, and GSTT1 genetic variability in Turkish and worldwide populations. Am. J. Hum. Biol. 2015, 27, 310-316. [CrossRef] [PubMed]

71. Iorio, A.; Piacentini, S.; Polimanti, R.; De Angelis, F.; Calderon, R.; Fuciarelli, M. Functional variability of glutathione S-transferases in Basque populations. Am. J. Hum. Biol. 2014, 26, 361-366. [CrossRef] [PubMed] 
72. Hudson, T.J.; Anderson, W.; Artez, A.; Barker, A.D.; Bell, C.; Bernabé, R.R.; Bhan, M.K.; Calvo, F.; Eerola, I.; Gerhard, D.S.; et al. International network of cancer genome projects. Nature 2010, 464, 993-998. [CrossRef] [PubMed]

73. Thorn, C.F.; Klein, T.E.; Altman, R.B. Pharmacogenomics and bioinformatics: PharmGKB. Pharmacogenomics 2010, 11, 501-505. [CrossRef] [PubMed]

74. Cariaso, M.; Lennon, G. SNPedia: A wiki supporting personal genome annotation, interpretation and analysis. Nucleic Acids Res. 2012, 40, D1308-D1312. [CrossRef] [PubMed]

75. Zhao, Q.; Shi, X.; Xie, Y.; Huang, J.; Shia, B.; Ma, S. Combining multidimensional genomic measurements for predicting cancer prognosis: Observations from TCGA. Brief. Bioinform. 2015, 16, 291-303. [CrossRef] [PubMed]

76. McKenna, A.; Hanna, M.; Banks, E.; Sivachenko, A.; Cibulskis, K.; Kernytsky, A.; Garimella, K.; Altshuler, D.; Gabriel, S.; Daly, M.; et al. The genome analysis toolkit: A MapReduce framework for analyzing next-generation DNA sequencing data. Genome Res. 2010, 20, 1297-1303. [CrossRef] [PubMed]

77. Purcell, S.; Neale, B.; Todd-Brown, K.; Thomas, L.; Ferreira, M.A.R.; Bender, D.; Maller, J.; Sklar, P.; de Bakker, P.I.W.; Daly, M.J.; et al. PLINK: A tool set for whole-genome association and population-based linkage analyses. Am. J. Hum. Genet. 2007, 81, 559-575. [CrossRef] [PubMed]

78. Liu, J.Z.; McRae, A.F.; Nyholt, D.R.; Medland, S.E.; Wray, N.R.; Brown, K.M.; Hayward, N.K.; Montgomery, G.W.; Visscher, P.M.; Martin, N.G.; Macgregor, S. A versatile gene-based test for genome-wide association studies. Am. J. Hum. Genet. 2010, 87, 139-145. [CrossRef] [PubMed]

79. Mishra, A.; Macgregor, S. VEGAS2: Software for more flexible gene-based testing. Twin Res. Hum. Genet. 2015, 18, 86-91. [CrossRef] [PubMed]

80. Excoffier, L.; Lischer, H.E.L. Arlequin suite ver 3.5: A new series of programs to perform population genetics analyses under Linux and Windows. Mol. Ecol. Resour. 2010, 10, 564-567. [CrossRef] [PubMed]

81. Barrett, J.C.; Fry, B.; Maller, J.; Daly, M.J. Haploview: Analysis and visualization of LD and haplotype maps. Bioinformatics 2005, 21, 263-265. [CrossRef] [PubMed]

82. Broman, K.W.; Wu, H.; Sen, S.; Churchill, G.A. R/qt1: QTL mapping in experimental crosses. Bioinformatics 2003, 19, 889-890. [CrossRef] [PubMed]

83. Prokop, M.; Damborský, J.; Koca, J. TRITON: In silico construction of protein mutants and prediction of their activities. Bioinformatics 2000, 16, 845-846. [CrossRef] [PubMed]

84. Prokop, M.; Adam, J.; Kríz, Z.; Wimmerová, M.; Koca, J. TRITON: A graphical tool for ligand-binding protein engineering. Bioinformatics 2008, 24, 1955-1956. [CrossRef] [PubMed]

85. Ng, P.C.; Henikoff, S. SIFT: Predicting amino acid changes that affect protein function. Nucleic Acids Res. 2003, 31, 3812-3814. [CrossRef] [PubMed]

86. Adzhubei, I.A.; Schmidt, S.; Peshkin, L.; Ramensky, V.E.; Gerasimova, A.; Bork, P.; Kondrashov, A.S.; Sunyaev, S.R. A method and server for predicting damaging missense mutations. Nat. Methods 2010, 7, 248-249. [CrossRef] [PubMed]

87. Zhang, Y.; Sun, Y.; Chen, T.; Hu, H.; Xie, W.; Qiao, Z.; Ding, N.; Xie, L.; Li, S.; Wang, W.; et al. Genetic variations rs11892031 and rs401681 are associated with bladder cancer risk in a Chinese population. Int. J. Mol. Sci. 2014, 15, 19330-19341. [CrossRef] [PubMed]

88. Modgil, S.; Lahiri, D.K.; Sharma, V.L.; Anand, A. Role of early life exposure and environment on neurodegeneration: Implications on brain disorders. Transl. Neurodegener. 2014, 3, 9. [CrossRef] [PubMed]

89. Rahman, K. Studies on free radicals, antioxidants, and co-factors. Clin. Interv. Aging 2007, 2, $219-236$. [PubMed]

90. Liao, R.; Ye, M.; Liu, C.; Ye, D. An updated meta-analysis: Risk conferred by glutathione S-transferases (GSTM1 and GSTT1) polymorphisms to age-related cataract. J. Ophthalmol. 2015, 2015, 103950. [CrossRef] [PubMed]

91. Katoh, T.; Yamano, Y.; Tsuji, M.; Watanabe, M. Genetic polymorphisms of human cytosol glutathione S-transferases and prostate cancer. Pharmacogenomics 2008, 9, 93-104. [CrossRef] [PubMed]

92. Wu, F.; Jasmine, F.; Kibriya, M.G.; Liu, M.; Cheng, X.; Parvez, F.; Islam, T.; Ahmed, A.; Rakibuz-Zaman, M.; Jiang, J.; et al. Interaction between arsenic exposure from drinking water and genetic polymorphisms on cardiovascular disease in Bangladesh: A prospective case-cohort study. Environ. Health Perspect. 2015, 123, 451-457. [CrossRef] [PubMed] 
93. Hsu, L.-I.; Wu, M.-M.; Wang, Y.-H.; Lee, C.-Y.; Yang, T.-Y.; Hsiao, B.-Y.; Chen, C.-J. Association of environmental arsenic exposure, genetic polymorphisms of susceptible genes, and skin cancers in Taiwan. Biomed Res. Int. 2015, 2015, 892579. [CrossRef] [PubMed]

94. Moyer, A.M.; Sun, Z.; Batzler, A.J.; Li, L.; Schaid, D.J.; Yang, P.; Weinshilboum, R.M. Glutathione pathway genetic polymorphisms and lung cancer survival after platinum-based chemotherapy. Cancer Epidemiol. Biomarkers Prev. 2010, 19, 811-821. [CrossRef] [PubMed]

95. Hong, G.-S.; Heun, R.; Jessen, F.; Popp, J.; Hentschel, F.; Kelemen, P.; Schulz, A.; Maier, W.; Kölsch, H. Gene variations in GSTM3 are a risk factor for Alzheimer's disease. Neurobiol. Aging 2009, 30, 691-696. [CrossRef] [PubMed]

96. Sharma, E.; Mustafa, M.; Pathak, R.; Guleria, K.; Ahmed, R.S.; Vaid, N.B.; Banerjee, B.D. A case control study of gene environmental interaction in fetal growth restriction with special reference to organochlorine pesticides. Eur. J. Obstet. Gynecol. Reprod. Biol. 2012, 161, 163-169. [CrossRef] [PubMed]

97. Schwartz, D.A. Environmental genomics and human health. G. Ital. Med. Lav. Ergon. 2011, 33, 31-34. [PubMed]

98. Jinek, M.; Chylinski, K.; Fonfara, I.; Hauer, M.; Doudna, J.A.; Charpentier, E. A programmable dual-RNA-guided DNA endonuclease in adaptive bacterial immunity. Science 2012, 337, 816-821. [CrossRef] [PubMed]

99. Mali, P.; Yang, L.; Esvelt, K.M.; Aach, J.; Guell, M.; DiCarlo, J.E.; Norville, J.E.; Church, G.M. RNA-guided human genome engineering via Cas9. Science 2013, 339, 823-826. [CrossRef] [PubMed]

100. Cong, L.; Ran, F.A.; Cox, D.; Lin, S.; Barretto, R.; Habib, N.; Hsu, P.D.; Wu, X.; Jiang, W.; Marraffini, L.A.; et al. Multiplex genome engineering using CRISPR/Cas systems. Science 2013, 339, 819-823. [CrossRef] [PubMed]

101. Collins, F.S.; Varmus, H. A new initiative on precision medicine. N. Engl. J. Med. 2015, 372, $793-795$. [CrossRef] [PubMed]

(C) 2016 by the authors; licensee MDPI, Basel, Switzerland. This article is an open access article distributed under the terms and conditions of the Creative Commons by Attribution (CC-BY) license (http://creativecommons.org/licenses/by/4.0/). 